ISSN (print): 2502-7816; ISSN (online): 2503-524X

Available online at https:/ / ejournal.unib.ac.id/index.php/joall/index doi: http://dx.doi.org/10.33369/joall.v5i1.9063

\title{
THE LANGUAGE CHOICE OF CHINESE COMMUNITY IN MEDAN: A SOCIOLINGUISTICS STUDY
}

\author{
Vivi Adryani Nasution', Niza Ayuningtias² \\ Universitas Sumatera Utara1,2 \\ Corresponding email: vivi.adryani@usu.ac.id
}

\begin{abstract}
This study aims to describe the manifestation of language choice and the dominant factors of determining language choice among Chinese community inter-ethnic and intra-ethnic relations in Medan. This study used descriptive qualitative method emphasized on a multiethnic and multilingual Chinese community background. The sociolinguistic theory of language choice focused on the domain features involving family and occupation domains was used as the basis of this study. It applied Miles and Huberman technique for analyzing the data and the Bungin formula for calculating the data. Of the 80 respondents, the results of the questionnaire showed that the Hokkien sub-ethnic was the dominant sub-ethnic in Medan compared to other Chinese sub-ethnicities. The manifestation of language choice in the domain of family and occupation especially in inter-ethnic relation is dominated by vernacular language, especially Hokkien language although respondents come from non-Hokkien ethnic. However, Indonesia language becomes the main language used related to intra-ethnic relation. In addition, the dominant language choice factor is influenced by Chinese participant's cultural backgrounds similarity.
\end{abstract}

Keywords: Chinese community, domain, language choice, Medan, sociolinguistics

\section{INTRODUCTION}

Medan is one of heterogeneous cities in Indonesia. One of the heterogeneities can be seen from the amount of vernacular languages and ethnicities in Medan such as Melayunese, Bataknese, Karonese, Acehnese, Padangnese, Javanese, Chinese, and so on. People in Medan use Indonesian language as national language. However, the heterogeneity of vernacular languages is still used as language choice for daily interactions of each ethnic community member One of them is the Chinese community. Chinese community in Medan is one of ethnic communities in Medan that plays an important role in the economy of Medan.

Based on the census of population in 2000 and 2010, Chinese community in Sumatera Utara consists of 353.259 and 340.325 people in 
respectively. In an interview with Mr. Tomi Wistan as the Secretary of Indonesian-Tionghoa Association (INTI), based on the 2019 election in Medan, 15\% of the voters were Chinese. However, since 2010 there has not been any data update regarding to the amount of Chinese population in Sumatera Utara particularly in Medan.

The Chinese community is not a homogeneous community. They also differ in culture, political orientation, and economic background. In culture, Chinese community consist of sub ethnic communities such as Hokkian, Hakka, Konghu, Tiociu, Khek, Hai Lo Hong, Hokciu, and many more. Each of the Chinese sub ethnic communities has their own vernacular language used by the members of the sub ethnic community to communicate to each other and to other sub ethnic community members. The Hokkian Chinese sub ethnic community has the most members. Based on the first survey in several Chinese community members in Medan, the interaction among Hakka, Kanton, Konghu, Tiociu and other sub ethnic fellow in Chinese community or also called inter-ethnic and sometimes sub-ethnic have to choose the Hokkian language to communicate because Hokkian is the Chinese sub-ethnic community that has the most members so the Hokkian language dominates other Chinese sub ethnic languages.

In a book titled "Tionghoa Medan, Komunitas Paling Kontroversial di Indonesia", it is stated that "The main characteristic of Medanese Chinese is speaking in a very typical Hokkian language" (Setiawan, 2018). From the excerpt of the book, it can be concluded that the majority of Chinese community members in Medan use Hokkian language in inter-ethnic relations, and Hokkian language in Medan has its own characteristics, often called Medanese Hokkian.

If two or more languages are used alternately by the same speaker, then it can be said that those languages are in contact with each other. In the language contact among bilingual society, language phenomenon as an object of sociolinguistics study is often found, such as language choice. This language choice results a language mixing phenomenon. The birth of language choice and language attitude phenomenon is caused by the speaker having two languages to use alternately, as seen in Chinese community in Medan that can be categorized as bilingualism. The language phenomenon that possibly occurs as the result of language contact in sociolinguistics is called bilingualism (Chaer \& Agustina, 2004). Bilingualism is the use of two languages alternately by a speaker in their contact with other people (Mackey, 1962).

Language choice as a social phenomenon is not only influenced by linguistic factors but also external factors. Language choice is closely related to the situation of the speaker's social community. The difference in age, and level of education can affect people's language choice in their 
communication with other people. Other than that, the situation In which the conversation happens also affects how a language will be used.

According to Fasold, language choice is a person in bilingual or multilingual community speaking two or more languages and has to choose which language to use (Fasold, 1984). To see the choice and the use of language in speakers, domain theory is needed. Domain is a term created by Joshua Fishman. He defines domain as an abstract illustration of sociocultural from communication topics, relations between communicators, and where the communication takes place according to the social structure of the speakers. Certain social factors, speakers, social context of the conversation, functions and topics of the conversation are important in the consideration of language choice in different kinds of speakers (Fishman, 1972).

The meeting of one individual with other individuals that have different or same language background in a conversation can create many variations of language use. This makes the speaker choose which language to use according to the context or situation of the conversation. Based on the multilingual phenomenon in multicultural society like the Chinese community above, this study is entitled "The Language Choice of Chinese Community in Medan: A Sociolinguistics Study"

A study related to language choice in Chinese community has also been done by Chong Shin, "The Chinese Community in West Kalimantan: A Review of Language Choice in Sekadau City". This study describes the condition of language choice of Chinese community in Sekadau city, West Kalimantan. In Sekadau, there are three main ethnics, Malay, Dayaknese, and Chinese. The Chinese community consists of two sub ethnic communities, Khek (majority) and Hoklo (minority). There are 12 languages used in Sekadau, but the 4 dominant languages used by the Chinese community in Sekadau are Indonesian, Malay language with Sekadau dialect, Khek and Hoklo.

This study used sociolinguistics theory focused on social determination involving family, society, religion and culture domain. The result of the study shows that Sekadau, Khek and Hoklo languages are dominantly used in Chinese communities. On one hand, Indonesian language is used in formal situation meanwhile Malay language with Sekadau dialect is used in informal situation. On the other hand, related to religion activities, the language used depends on the religion of the society. The Christian Chinese mostly use Indonesian language, but Konghu Chinese use Konghu language. Furthermore, for cultural occasions, such as wedding ceremony, they use Mandarin (Shin, 2007).

Wulan in her study titled 城市化进程中城市新移民的语言选择一以长 沙位列, New Language Choice of Urban Migrants in Urbanization Process A Case Study in Changsha City. The study shows that new migrants in cities 
come from urbanization and promoting the urbanization process. Due to the difference in immigration place, the dialect of new migrants in the city varies greatly. In order to be more adaptable with urban life, they have to face different communication objects in different communication situations. Language social prestige and language attitude, individual needs and language ability of new migrants in cities affect the language choice of new migrants in cities. After conducting questionnaire survey, observation and interview in Changsha city, there are four kinds of language used by new urban migrants: a shift of local dialect to local dialect in the area, Mandarin, and third local dialect. Moving out from local dialect refers to the birth place of the new urban migrants. Moving to local dialect refers to the dialect of the city where the new migrants live and work. Mandarin is a standard language of modern Chinese promoted to the entire Chinese community. The third local dialect language refers to new city shifts besides emigration and immigration. The dialects of other regions which are still owned by the community. The third local language hardly ever been used in daily life (吴 岗, 2018).

\section{METHODS}

The type of study is a field study. The method used in the study is descriptive-qualitative method. The data collection is conducted by observation, questionnaire, and interview. The method of data collection is also conducted by using Sudaryanto method namely Involved Conversation Observation Technique (Sudaryanto, 2015). In this case, the researcher participated in the conversation and scrutinized the conversation through interview. The participation of the researcher is active flexible and the result of the interview uses recording technique. The data collection technique applied is Purposive Accidental Sampling. Purposive Accidental Sampling technique is where the data is obtained randomly or choosing an individual or group to meet in the appointed location (Mahsun, 2005).

\section{Participants}

Respondents of the study are 80 Chinese people domiciled in Medan aged 15-60 years old. There were 69 female and 11 male. 42 respondents are bachelor degree. 63 respondents are multilingual, mastering foreign, vernacular and national languages.

\section{Instruments}

The main instrument of the study is questionnaire distribution and unstructured interview. The determination of informants is based on ethnic, age, education level, vernacular language and foreign language spoken. In the questionnaire there are questions related to family and accupation 
domains. Each question consists of 6 answer choices and respondents can choose more than one answer and add their own answer based on their actual condition. Respondents can also write down the reasons choosing the answer.

\section{Data Analysis Procedures}

The result of the collected questionnaires uses data analysis technique by Miles and Huberman. The three steps of data analysis are data reduction, data presentation and conclusion (Miles \& Huberman, 1992). The data calculation uses Bungin formula (Bungin, 2008).

\section{FINDINGS}

$$
n=\frac{f x}{N} \times 100 \%
$$

From 80 questionnaires, the data are obtained as shown by Table 1:

Table 1. The Amount of Chinese Sub Ethnic Respondents in Medan

\begin{tabular}{|c|c|c|}
\hline \multirow[b]{2}{*}{ Sub Ethnics } & \multicolumn{2}{|c|}{ Number of Respondents } \\
\hline & Number & $\%$ \\
\hline Hokkian (HK) & 45 & 56.3 \\
\hline Tiociu (TC) & 14 & 17.5 \\
\hline Konghu (KH) & 11 & 13.7 \\
\hline Hakka (HA) & 5 & 6.2 \\
\hline Hai Lho Khong (HLH) & 3 & 3.7 \\
\hline Hok Chio (HC) & 1 & 1.3 \\
\hline Khek (K) & 1 & 1.3 \\
\hline TOTAL & 80 & 100 \\
\hline
\end{tabular}

From 80 respondents, 7 Chinese sub ethnic communities are found. Table 1 shows that $56.3 \%$ of the dominant sub ethnic community are Hokkian. Followed by Tiuciu and Konghu sub ethnic communities. Whereas Hakka, Hai Lo Khong, Khek, and Hokciu are the minorities. The result of the questionnaire shows that the Hokkian sub ethnic community dominates other sub ethnic communities in Medan. Likewise said by the secretary of INTI Medan, Mr. Tomi Wistan and Mr. Setiawan, that the majority of Chinese ethnic sub-groups in Medan are Hokkien.

Table 2. The Comparison of the Amount of Chinese Sub Ethnic Language Mastery

\begin{tabular}{cccc}
\hline $\begin{array}{c}\text { Sub Ethnics } \\
\text { Hokkian (HK) }\end{array}$ & $\begin{array}{c}\text { Number of } \\
\text { Respondents }\end{array}$ & $\begin{array}{c}\text { Vernacular } \\
\text { Language } \\
\text { Mastery }\end{array}$ & $\begin{array}{c}\text { Non Vernacular } \\
\text { Language } \\
\text { Mastery }\end{array}$ \\
\hline Hokkian (HK) & 45 & 43 & 2 \\
\hline Tiociu (TC) & 14 & 6 & 8 \\
\hline Konghu (KH) & 11 & 4 & 7 \\
\hline Hakka (HA) & 5 & 4 & 1 \\
\hline
\end{tabular}


Vivi Adryani Nasution, Niza Ayuningtias

\begin{tabular}{cccc}
\hline $\begin{array}{c}\text { Sub Ethnics } \\
\text { Hokkian (HK) }\end{array}$ & $\begin{array}{c}\text { Number of } \\
\text { Respondents }\end{array}$ & $\begin{array}{c}\text { Vernacular } \\
\text { Language } \\
\text { Mastery }\end{array}$ & $\begin{array}{c}\text { Non Vernacular } \\
\text { Language } \\
\text { Mastery }\end{array}$ \\
\hline Hai Lho Khong & 3 & - & 3 \\
\hline (HLH) & - & - & 1 \\
\hline Hok Chio (HC) & 1 & - & 1 \\
\hline Khek (K) & 1 & - & 1 \\
\hline
\end{tabular}

Table 2 shows the incompatibility of the amount of sub ethnic community members with the amount of native vernacular language mastery. It can be seen in the Table that there are 14 of Tiuciu sub ethnic respondents, but only the 3 of them master the Tiuciu sub ethnic language. Same goes to respondents of Konghu and Hakka sub ethnic community. Meanwhile in Hai Lo Hong, Khek, and Hokciu, the sub ethnic community members can no longer speak in their native vernacular language, they switched their language use to Hokkien language.

Based on Table 2, it can also be seen that there are 2 respondents that do not master the Hokkien language. From the result of the interview, it is stated that the two respondents do not master the vernacular language because their parents no longer use the vernacular language, instead they use foreign language such as Mandarin or English for daily conversation especially in the family domain, causing the foreign language become their first language and Indonesian language become their second language. This is also supported by their entry to international school that uses foreign language as the first language, the use of vernacular language is not advisable in the school environment.

\section{DISCUSSION}

The discussion of language choice of Chinese community in Medan is focused in family and occupation domain A home is where the family gathers so the use of minority language or vernacular language starts at home. And at work is where the majority of Chinese community socializes with multi ethnics or intra-ethnics, so it can be seen what language is going to be used in inter-ethnics and intra-ethnics communication.

\section{Family Domain}

Table 3. Language Choice of Family domain at Home

\begin{tabular}{cccc}
\hline \multirow{2}{*}{ Answers } & Selected & \multicolumn{2}{c}{ Total } \\
\cline { 3 - 4 } & Answers & Respondents & $\mathbf{( \% )}$ \\
\hline \multirow{3}{*}{$\mathrm{A}$} & $\mathrm{HK}$ & 43 & 53,8 \\
\cline { 2 - 4 } & $\mathrm{TU}$ & 2 & 2,5 \\
\cline { 2 - 4 } & $\mathrm{HA}$ & 2 & 2,5 \\
\hline
\end{tabular}




\begin{tabular}{cccc}
\hline \multirow{2}{*}{ Answers } & $\begin{array}{c}\text { Selected } \\
\text { Answers }\end{array}$ & \multicolumn{2}{c}{ Total } \\
\cline { 2 - 4 } & Respondents & $\mathbf{( \% )}$ \\
\cline { 2 - 4 } & $\mathrm{KH}$ & 3 & 3.8 \\
\cline { 2 - 4 } & $\mathrm{K}$ & 0 & 0 \\
\cline { 2 - 4 } & $\mathrm{HC}$ & 0 & 0 \\
\cline { 2 - 4 } $\mathrm{B}$ & $\mathrm{HLH}$ & 0 & 0 \\
\hline $\mathrm{C}$ & $\mathrm{M}$ & 6 & 7.5 \\
\hline \multirow{2}{*}{$\mathrm{D}$} & $\mathrm{E}$ & 2 & 2,5 \\
\cline { 2 - 4 } & $\mathrm{HK} / \mathrm{BI}>\mathrm{HK}$ & 12 & 0 \\
\cline { 2 - 4 } & $\mathrm{HK} / \mathrm{BI}>\mathrm{BI}$ & 1 & 1,2 \\
\cline { 2 - 4 } & $\mathrm{TU} / \mathrm{BI}>\mathrm{TU}$ & 1 & 1,2 \\
\cline { 2 - 4 } & $\mathrm{HA} / \mathrm{BI}>\mathrm{HA}$ & 2 & 2,5 \\
\cline { 2 - 4 } & $\mathrm{KH} / \mathrm{BI}>\mathrm{KH}$ & 1 & 1,2 \\
\hline E & $\mathrm{HK} / \mathrm{M}>\mathrm{HK}$ & 2 & 2,5 \\
\cline { 2 - 4 } & $\mathrm{HK} / \mathrm{M}>\mathrm{M}$ & 1 & 1,2 \\
\hline F & $\mathrm{BI} / \mathrm{M}>\mathrm{M}$ & 1 & 1,2 \\
\cline { 2 - 4 } & $\mathrm{BI} / \mathrm{M}>\mathrm{BI}$ & 1 & 1,2 \\
\hline & Total & 80 & 100 \\
\hline
\end{tabular}

Based on Table 3, if compared with language choice in which the language use focuses only in one sub ethnic language between TU, HA, KH language, TU, HA, KH Chinese sub ethnic community still choose their native vernacular language in family domain although there is only a few of them. Based on Table 2, the respondents of Khek, Hokciu, and Hai Lo Hong sub ethnics community no longer use their vernacular language and they use Hokkian language instead. As can be seen in Table 3 the language choice of $\mathrm{HK}$ has the highest percentage, the language choice of Hokkian dominates other sub ethnic languages because a half of non-Hokkian sub ethnic community switched their language to Hokkian, Indonesian, and Mandarin.

If viewed in terms of comparison of the use of two languages between vernacular language and Indonesian language, they are $\mathrm{HK} / \mathrm{BI}>\mathrm{HK} 12$ respondents; TU/BI>TU 1 respondent; $\mathrm{HA} / \mathrm{BI}>\mathrm{HA} 2$ respondents; $\mathrm{KH} / \mathrm{BI}>\mathrm{KH} 1$ respondent. The use of $\mathrm{HK}$ and Mandarin language (M) also shows that HK language is more often used in family domain, but the use of Indonesian language and Mandarin language has equal comparison.

Based on the result of the interview with non-Hokkian sub ethnic respondents, most parents do not use the sub ethnic native language to communicate with their children. The reason of not using the sub ethnic native language to their children is because most of their parents can no longer speak or no longer fluently speak in their native sub ethnic language too, other than that, the parents assume that their environment is dominated 
Vivi Adryani Nasution, Niza Ayuningtias

by Hokkian sub ethnic community and many of non-Hokkian sub ethnic community have switched their language to Hokkian language. Therefore, in order to ease their communication and interaction with other Chinese community, they choose Hokkian language to be their first language in communication. This makes Hokkian language become first language in most of 6 other Chinese sub ethnic community.

Table 4 The Language Choice When Discussing About Education with Children/ Parents at home

\begin{tabular}{cccc}
\hline \multirow{2}{*}{ Answers } & $\begin{array}{c}\text { Selected } \\
\text { Answers }\end{array}$ & \multicolumn{2}{c}{ Total } \\
\cline { 2 - 4 } & Respondents & $\mathbf{( \% )}$ \\
\hline \multirow{2}{*}{$\mathrm{A}$} & $\mathrm{HK}$ & 34 & 42,5 \\
\cline { 2 - 4 } & $\mathrm{TU}$ & 3 & 3.7 \\
\cline { 2 - 4 } & $\mathrm{HA}$ & 4 & 5 \\
\cline { 2 - 4 } & $\mathrm{KH}$ & 3 & 3.7 \\
\hline $\mathrm{B}$ & $\mathrm{BI}$ & 4 & 5 \\
\hline $\mathrm{C}$ & $\mathrm{M}$ & 2 & 2,5 \\
\hline $\mathrm{D}$ & $\mathrm{HK} / \mathrm{BI}>\mathrm{HK}$ & 14 & 17.5 \\
\cline { 2 - 4 } & $\mathrm{HK} / \mathrm{BI}>\mathrm{BI}$ & 4 & 5 \\
\cline { 2 - 4 } & $\mathrm{TU} / \mathrm{BI}>\mathrm{TU}$ & 3 & 3.7 \\
\cline { 2 - 4 } & $\mathrm{HA} / \mathrm{BI}>\mathrm{HA}$ & 2 & 2,5 \\
\cline { 2 - 4 } & $\mathrm{KH} / \mathrm{BI}>\mathrm{KH}$ & 2 & 2,5 \\
\hline $\mathrm{E}$ & $\mathrm{HK} / \mathrm{M}>\mathrm{HK}$ & 1 & 1,2 \\
\cline { 2 - 4 } & $\mathrm{HK} / \mathrm{M}>\mathrm{M}$ & 1 & 1,2 \\
\hline $\mathrm{F}$ & $\mathrm{BI} / \mathrm{M}>\mathrm{M}$ & 2 & 2,5 \\
\cline { 2 - 4 } & $\mathrm{BI} / \mathrm{M}>\mathrm{BI}$ & 1 & 1,2 \\
\hline & Total & 80 & 100 \\
\hline
\end{tabular}

Table 5 The Language Choice When Discussing About Personal Stuffs with Children/Parents at Home

\begin{tabular}{cccc}
\hline \multirow{2}{*}{ Answers } & $\begin{array}{c}\text { Selected } \\
\text { Answers }\end{array}$ & \multicolumn{2}{c}{ Total } \\
\cline { 2 - 4 } & Respondents & $\mathbf{( \% )}$ \\
\hline A & $\mathrm{HK}$ & 32 & 40 \\
\cline { 2 - 4 } & $\mathrm{TU}$ & 5 & 6,2 \\
\cline { 2 - 4 } & $\mathrm{HA}$ & 6 & 7.5 \\
\cline { 2 - 4 } & $\mathrm{KH}$ & 4 & 5 \\
\hline $\mathrm{B}$ & $\mathrm{BI}$ & 6 & 7.5 \\
\hline $\mathrm{C}$ & $\mathrm{M}$ & 2 & 2,5 \\
\hline $\mathrm{D}$ & $\mathrm{HK} / \mathrm{BI}>\mathrm{HK}$ & 11 & 13.7 \\
\cline { 2 - 4 } & $\mathrm{HK} / \mathrm{BI}>\mathrm{BI}$ & 3 & 3.7 \\
\cline { 2 - 4 } & $\mathrm{TU} / \mathrm{BI}>\mathrm{TU}$ & 2 & 2,5 \\
\cline { 2 - 4 } & $\mathrm{HA} / \mathrm{BI}>\mathrm{HA}$ & 2 & 2,5 \\
\cline { 2 - 4 } & $\mathrm{KH} / \mathrm{BI}>\mathrm{KH}$ & 2 & 2,5 \\
\hline
\end{tabular}




\begin{tabular}{cccc}
\hline \multirow{2}{*}{ Answers } & \multirow{2}{*}{$\begin{array}{c}\text { Selected } \\
\text { Answers }\end{array}$} & \multicolumn{2}{c}{ Total } \\
\cline { 3 - 4 } & Respondents & $\mathbf{( \% )}$ \\
\hline \multirow{2}{*}{$\mathrm{E}$} & $\mathrm{HK} / \mathrm{M}>\mathrm{HK}$ & 1 & 1,2 \\
\cline { 2 - 4 } & $\mathrm{HK} / \mathrm{M}>\mathrm{M}$ & 2 & 2,5 \\
\hline \multirow{2}{*}{$\mathrm{F}$} & $\mathrm{BI} / \mathrm{M}>\mathrm{M}$ & 1 & 1,2 \\
\cline { 2 - 4 } & $\mathrm{BI} / \mathrm{M}>\mathrm{BI}$ & 1 & 1,2 \\
\hline \multicolumn{2}{c}{ Total } & 80 & 100 \\
\hline
\end{tabular}

As seen in Table 4 and Table 5 containing the language choice when discussing about education and personal stuffs with children/parents at home, if viewed in terms of language use that focused in only one language, it is the vernacular language. The use of vernacular language still dominates due to the habit, especially at home, because the home is where the participants feel more free and relaxed so they will choose the language that fits to the situation. If viewed in between the use of two languages such as vernacular language and Indonesian language (BI) or Mandarin (M) when discussing about education and personal stuffs, also shows that vernacular language is the most frequently used language. Indonesian language is used when there are things or words that cannot be expressed with the vernacular language. Mandarin language is used if the parents or children use Mandarin language to communicate with each other at home, rather than the vernacular or Indonesian language.

\section{Occupation Domain}

Table 6 The Language Choice in the Communication with Chinese Co-Workers in the Office

\begin{tabular}{|c|c|c|c|}
\hline \multirow{2}{*}{ Answers } & \multirow{2}{*}{$\begin{array}{l}\text { Selected } \\
\text { Answers }\end{array}$} & \multicolumn{2}{|c|}{ Total } \\
\hline & & Respondents & $(\%)$ \\
\hline \multirow[t]{7}{*}{$\mathrm{A}$} & HK & 40 & 50 \\
\hline & TU & 0 & 0 \\
\hline & $\mathrm{HA}$ & 0 & 0 \\
\hline & $\mathrm{KH}$ & 0 & 0 \\
\hline & $\mathrm{K}$ & 0 & 0 \\
\hline & $\mathrm{HC}$ & 0 & 0 \\
\hline & $\mathrm{HLH}$ & 0 & 0 \\
\hline $\mathrm{B}$ & $\mathrm{BI}$ & 11 & 13,7 \\
\hline \multirow[t]{2}{*}{$\mathrm{C}$} & $\mathrm{M}$ & 3 & 3.7 \\
\hline & $E$ & 2 & 2,5 \\
\hline \multirow[t]{2}{*}{$\mathrm{D}$} & $\mathrm{HK} / \mathrm{BI}>\mathrm{HK}$ & 12 & 15 \\
\hline & $\mathrm{HK} / \mathrm{BI}>\mathrm{BI}$ & 4 & 5 \\
\hline \multirow[t]{2}{*}{$\mathrm{E}$} & $\mathrm{HK} / \mathrm{M}>\mathrm{HK}$ & 2 & 2,5 \\
\hline & $\mathrm{HK} / \mathrm{M}>\mathrm{M}$ & 1 & 1,2 \\
\hline $\mathrm{F}$ & $\mathrm{BI} / \mathrm{M}>\mathrm{BI}$ & 2 & 2,5 \\
\hline
\end{tabular}


Vivi Adryani Nasution, Niza Ayuningtias

\begin{tabular}{cccc}
\hline \multirow{2}{*}{ Answers } & $\begin{array}{c}\text { Selected } \\
\text { Answers }\end{array}$ & \multicolumn{2}{c}{ Total } \\
\cline { 2 - 4 } & Respondents & $\mathbf{( \% )}$ \\
\cline { 2 - 4 } $\mathrm{BI} / \mathrm{M}>\mathrm{M}$ & 1 & 1,2 \\
\hline $\mathrm{BI} / \mathrm{E}>\mathrm{BI}$ & 2 & 2,5 \\
\hline Total & 80 & 100 \\
\hline
\end{tabular}

Based on Table 6, the language choice of Chinese community in Medan in their interaction with their Chinese co-workers in the office is Hokkian language. There found none of the non-Hokkian sub ethnic community uses their vernacular language, this is caused by most of the Chinese community in Medan have mastered the Hokkian language although they are not a native Hokkian. In order to ease the communication between Chinese community members, Hokkian language is chosen as the first language in the office. Besides, choosing the vernacular language in interacting with Chinese fellow gives familiarity impression.

There also found respondents who choose to use Indonesian language, the reasons of choosing Indonesian language are (1) the respondents want to keep the professionalism in the work environment and tolerate other non-Chinese co-workers when they are around, (2) there are some respondents that do not speak their vernacular language fluently so they prefer using Indonesian language for communication. The foreign language choice also occurs such as Mandarin (1) as an alternative language for respondents and their interlocutors who cannot speak in the vernacular language and (2) to practice the fluency of their Mandarin language skill. English (E) is used when the respondent is working in a work environment that requires English.

Table 7 The Language Choice in the Communication with Chinese Leaders in the Office

\begin{tabular}{cccc}
\hline \multirow{2}{*}{ Answers } & \multirow{2}{*}{$\begin{array}{c}\text { Selected } \\
\text { Answers }\end{array}$} & \multicolumn{2}{c}{ Total } \\
\cline { 3 - 4 } & Respondents & $\mathbf{( \% )}$ \\
\hline $\mathrm{A}$ & $\mathrm{HK}$ & 27 & 33.7 \\
\hline $\mathrm{B}$ & $\mathrm{BI}$ & 16 & 20 \\
\hline $\mathrm{C}$ & $\mathrm{M}$ & 3 & 3.7 \\
\cline { 2 - 4 } & $\mathrm{E}$ & 2 & 2,5 \\
\hline $\mathrm{D}$ & $\mathrm{HK} / \mathrm{BI}>\mathrm{HK}$ & 9 & 11.3 \\
\cline { 2 - 4 } & $\mathrm{HK} / \mathrm{BI}>\mathrm{BI}$ & 11 & 13.8 \\
\hline $\mathrm{E}$ & $\mathrm{HK} / \mathrm{M}>\mathrm{HK}$ & 3 & 3.7 \\
\cline { 2 - 4 } & $\mathrm{HK} / \mathrm{M}>\mathrm{M}$ & 2 & 2,5 \\
\hline \multirow{2}{*}{$\mathrm{F}$} & $\mathrm{BI} / \mathrm{M}>\mathrm{BI}$ & 3 & 3.7 \\
\cline { 2 - 4 } & $\mathrm{BI} / \mathrm{M}>\mathrm{M}$ & 2 & 2,5 \\
\cline { 2 - 4 } & $\mathrm{BI} / \mathrm{E}>\mathrm{BI}$ & 2 & 2,5 \\
\hline \multicolumn{2}{c}{ Total } & 80 & 100 \\
\hline
\end{tabular}


Based on Table 7, Hokkian language still dominates the language choice and language use. Based on the result of the interview, this is caused by using vernacular language with the leaders in the office gives familiarity impression and eases the communication and interaction with the leaders, but the use of vernacular language only occurs in informal situations, not in formal situations or meetings. If the frequency of the use of HK language is compared with the use of Indonesian language, it only has a slight difference because the respondents want to keep the professionalism in the work environment and to give an impression of respect to the leader.

Table 8 The Language Choice in Meetings

\begin{tabular}{|c|c|c|c|}
\hline \multirow{2}{*}{ Answers } & \multirow{2}{*}{$\begin{array}{l}\text { Selected } \\
\text { Answers }\end{array}$} & \multicolumn{2}{|l|}{ Total } \\
\hline & & Respondents & $(\%)$ \\
\hline \multirow[t]{4}{*}{ A } & HK & 0 & 0 \\
\hline & TU & 0 & 0 \\
\hline & HA & 0 & 0 \\
\hline & $\mathrm{KH}$ & 0 & 0 \\
\hline $\mathrm{B}$ & $\mathrm{BI}$ & 73 & 91.3 \\
\hline \multirow[t]{2}{*}{$\mathrm{C}$} & $\mathrm{M}$ & 2 & 2,5 \\
\hline & $\mathrm{E}$ & 2 & 2,5 \\
\hline \multirow[t]{3}{*}{$\mathrm{D}$} & $\mathrm{BI} / \mathrm{M}>\mathrm{BI}$ & 1 & 1,2 \\
\hline & $\mathrm{BI} / \mathrm{M}>\mathrm{M}$ & 1 & 1,2 \\
\hline & $\mathrm{BI} / \mathrm{E}>\mathrm{BI}$ & 1 & 1,2 \\
\hline \multicolumn{2}{|c|}{ Total } & 80 & 100 \\
\hline
\end{tabular}

Based on Table 8, it can be seen that meetings are formal situations and there are some participants that come from different backgrounds in the meeting. Hence, Indonesian language is used as the first language. This corresponds with the position of Indonesian language as national language that functions to connect people with different ethnicity and cultural background in in Indonesia. The reason of the language choice that refers to the use of two languages such as $\mathrm{BI} / \mathrm{M}>\mathrm{BI}$; $\mathrm{BI} / \mathrm{M}>\mathrm{M}$; $\mathrm{BI} / \mathrm{E}>\mathrm{BI}$ is because of the location factor that allows respondents to use Mandarin or English followed by Indonesian language.

Table 9 The Language Choice in the Communication with Chinese Co-Workers in Social Media

\begin{tabular}{cccc}
\hline \multirow{2}{*}{ Answers } & \multirow{2}{*}{$\begin{array}{c}\text { Selected } \\
\text { Answers }\end{array}$} & \multicolumn{2}{c}{ Total } \\
\cline { 3 - 4 } & Respondents & $\mathbf{( \% )}$ \\
\hline $\mathrm{A}$ & $\mathrm{HK}$ & 39 & 45,4 \\
\hline $\mathrm{B}$ & $\mathrm{BI}$ & 9 & 12 \\
\hline $\mathrm{C}$ & $\mathrm{M}$ & 1 & 1,3 \\
\cline { 2 - 4 } & $\mathrm{E}$ & 2 & 2,7 \\
\hline
\end{tabular}


Vivi Adryani Nasution, Niza Ayuningtias

\begin{tabular}{|c|c|c|c|}
\hline \multirow{2}{*}{ Answers } & \multirow{2}{*}{$\begin{array}{l}\text { Selected } \\
\text { Answers }\end{array}$} & \multicolumn{2}{|c|}{ Total } \\
\hline & & Respondents & $(\%)$ \\
\hline \multirow[t]{2}{*}{$\mathrm{D}$} & $\mathrm{HK} / \mathrm{BI}>\mathrm{HK}$ & 12 & 16 \\
\hline & $\mathrm{HK} / \mathrm{BI}>\mathrm{BI}$ & 7 & 9,3 \\
\hline \multirow[t]{2}{*}{$\mathrm{E}$} & $\mathrm{HK} / \mathrm{M}>\mathrm{HK}$ & 3 & 4 \\
\hline & $\mathrm{HK} / \mathrm{M}>\mathrm{BM}$ & 1 & 1,3 \\
\hline \multirow[t]{4}{*}{$\mathrm{F}$} & $\mathrm{BI} / \mathrm{M}>\mathrm{BI}$ & 2 & 2,7 \\
\hline & $\mathrm{BI} / \mathrm{M}>\mathrm{M}$ & 1 & 1,3 \\
\hline & $\mathrm{BI} / \mathrm{E}>\mathrm{BI}$ & 3 & 4 \\
\hline & tal & 80 & 100 \\
\hline
\end{tabular}

Table 10 The Language Choice in the Communication with Chinese Leaders in Social Media

\begin{tabular}{|c|c|c|c|}
\hline \multirow{2}{*}{ Answers } & \multirow{2}{*}{$\begin{array}{l}\text { Selected } \\
\text { Answers }\end{array}$} & \multicolumn{2}{|c|}{ Total } \\
\hline & & Respondents & $(\%)$ \\
\hline A & HK & 35 & 40 \\
\hline B & $\mathrm{BI}$ & 11 & 14,8 \\
\hline \multirow[t]{2}{*}{ C } & $\mathrm{M}$ & 2 & 2,7 \\
\hline & $E$ & 1 & 1,3 \\
\hline \multirow[t]{2}{*}{$\mathrm{D}$} & $\mathrm{HK} / \mathrm{BI}>\mathrm{HK}$ & 12 & 16 \\
\hline & $\mathrm{HK} / \mathrm{BI}>\mathrm{BI}$ & 14 & 18,7 \\
\hline \multirow[t]{2}{*}{$\mathrm{E}$} & $\mathrm{HK} / \mathrm{M}>\mathrm{HK}$ & 1 & 1,3 \\
\hline & $\mathrm{HK} / \mathrm{M}>\mathrm{M}$ & 1 & 1,3 \\
\hline \multirow[t]{4}{*}{ F } & $\mathrm{BI} / \mathrm{M}>\mathrm{BI}$ & 1 & 1,3 \\
\hline & $\mathrm{BI} / \mathrm{M}>\mathrm{M}$ & 1 & 1,3 \\
\hline & $\mathrm{BI} / \mathrm{E}>\mathrm{BI}$ & 1 & 1,3 \\
\hline & otal & 80 & 100 \\
\hline
\end{tabular}

Based on Table 9 and 10, the language choice in social media with both Chinese co-workers and Chinese leaders is also dominated by HK language. Habit and familiarity are the main reasons of choosing vernacular language in social media. Although HK dominates other languages, based on the interview respondents also often mix it with BI. Can be said that, Indonesian language plays an important role in overcoming miscommunications in the delivery of meaning.

Social media in here refers to written communication media. Based on the interview with the respondents, in written communication there are quite many miscommunications occur in the delivery of meaning by using vernacular language such as HK language, because HK language is categorized as a homograph language, where the lexical relations between words has the same writing but different pronunciation and meaning. HK language is a language that has intonation to distinguish meanings, but HK language does not have particular alphabets as written language so that 
sometimes in written communication in social media the participants have to guess the meaning of the written words. Due to the unavailability of particular alphabets in Chinese sub ethnic languages, the use of Indonesian language is needed to reduce miscommunications.

Table 11 The Language Choice in the Communication with Non-Chinese Fellows in the Office

\begin{tabular}{cccc}
\hline \multirow{2}{*}{ Answers } & $\begin{array}{c}\text { Selected } \\
\text { Answers }\end{array}$ & \multicolumn{2}{c}{ Total } \\
\cline { 3 - 4 } & Respondents & $\mathbf{( \% )}$ \\
\hline $\mathrm{A}$ & $\mathrm{V}$ & 0 & 0 \\
\hline $\mathrm{B}$ & $\mathrm{BI}$ & 73 & 90,7 \\
\hline $\mathrm{C}$ & $\mathrm{M}$ & 2 & 2,7 \\
\cline { 2 - 4 } & $\mathrm{E}$ & 2 & 2,7 \\
\hline $\mathrm{D}$ & $\mathrm{BI} / \mathrm{M}>\mathrm{BI}$ & 1 & 1,3 \\
\cline { 2 - 4 } & $\mathrm{BI} / \mathrm{M}>\mathrm{M}$ & 1 & 1,3 \\
\cline { 2 - 4 } & $\mathrm{BI} / \mathrm{E}>\mathrm{BI}$ & 1 & 1,3 \\
\hline \multicolumn{2}{c}{ Total } & 80 & 100 \\
\hline
\end{tabular}

The participant or the difference in ethnicity background proves that Indonesian language is the main language used in intra-ethnicity communication with co-workers/leaders at work. Mandarin and English has small percentage, because not all respondents-participants can use and speak in the language. Place and situation factors also affect the use of those foreign languages and when to use them. None Chinese respondents choose vernacular language $(\mathrm{V})$ to communicate with Non-Chinese. It is quite difficult to find Non-Chinese community mastering Chinese vernacular language.

\section{CONCLUSION AND SUGGESTION}

The manifestation of language choice in inter-ethnicity relations of Chinese community in Medan in family and occupation domain is dominated by vernacular language notably Hokkian language. Although the respondents are from different Chinese sub ethnic community but the dominant sub ethnic language used is Hokkian language. Based on the result of the interview with respondents, there are 56 non-Hokkian sub ethnic community members aged less than 60 years old that are passive and no longer speak their own vernacular language such as Hakka, Konghu, Tiuciu, and other sub ethnic languages. This caused by parents that no longer use and teach their vernacular language because their environment, Medan, is dominated by Hokkian sub ethnic community. Therefore, in order to make the children blend and communicate well with their Chinese fellows, Hokkian language is chosen as their first language and mother tongue in the majority of Chinese community in Medan. Besides using vernacular 
language, Mandarin language is also used as an alternative language in inter-ethnicity relations. Followed by Indonesian and English in certain condition, participant, place, and topics.

The manifestation of language choice in intra-ethnicity relations of Chinese community in Medan is Indonesian language. This caused by the significant difference of ethnicity backgrounds and the speakers who speak only Indonesian language as their first language in intra-ethnicity communication. Furthermore, in Medan, there is no vernacular language that can be chosen as a main language for daily communication in intraethnicity relations other than Indonesian language.

In this study, it can be found that Chinese community in Medan are multilingual speakers, so in their interaction, Chinese community in Medan will choose the language that correspondents to the factors of language choice. Based on the factors of language choice stated by Ervin-Tripp in social interactions (Grosjean, 1982), namely (1) setting (time and place) and circumstance, in this case this refers to the location notably house and office; informal and formal situations. Informal situation refers to family domain at home. Formal situation refers to the office. Although the respondents are in working situation where Indonesian language should be dominating as a formal language, but due to habit and familiarity factors they choose to use vernacular language, Hokkian language; (2) participants in interaction. Due to the cultural background similarity, Chinese community in Medan choose to use vernacular language with family, co-workers and leaders; (3) topics. It can be said that the Chinese community in Medan are used to use vernacular language in various conversation topics and; (4) the interaction function. If seen from the dominance of Hokkian language in family and occupation domain then the main factor in this study is the similarity of the participants' cultural background.

It has been such a habit in the life of Chinese community that vernacular language is used in every occasion, particularly with their Chinese fellows. If they have to choose between using vernacular language and Indonesian language to use in daily life, the Chinese community in Medan prefers their vernacular language, Hokkian. This shows the function and position of the vernacular language is higher than Indonesian language. On the other hand, this shows that the language maintenance is high. Although some of the Chinese sub ethnic community members switched their language to Hokkian, but as an alternative to keep using their vernacular language, they use Hokkian language to adapt with the dominant sub ethnic community. 
The Language Choice of Chinese Community...

\section{ACKNOWLEDGMENT}

This research was funded by TALENTA Universitas Sumatera Utara nomor: 4167/UN5.1.R/PPM/2019, 1 April 2019.

\section{REFERENCES}

Bungin, B. (2008). Analisis Data Penelitian Kualitatif. Jakarta: Raja Grafindo Persada.

Chaer, A., \& Agustina, L. (2004). Sosiolinguistik Perkenalan Awal. Jakarta: Rineka Cipta.

Fasold, R. (1984). The Sociolinguistic of Society. Oxford: Basil Blackwell.

Fishman, A. . (1972). Reading in The Sosiology of Language. Paris: Yeshiva.

Grosjean, F. (1982). Life with Two Languages. Cambridge: Harvard University Press.

Mackey, W. F. (1962). The Description of Bilingualism. Canadian Journal of Linguistic, 7, 51-58.

Mahsun. (2005). Metode Penelitian Bahasa. Jakarta: PT Raja Grafindo Persada.

Miles, M., \& Huberman, M. (1992). Analisis Data Kualitatif Buku Sumber Tentang Metode-Metode Baru. Jakarta: UIP.

Setiawan, E. (2018). Tionghoa Medan, Komunitas Paling Kontroversial di Indonesia. Jakarta Barat: PT Buku Pintar Indonesia.

Shin, C. (2007). Masyarakat Tionghoa Kalimantan Barat: Tinjauan Pemilihan Bahasa di Kota Sekadau. Linguistik Indonesia, 25(1), 19. https://doi.org/10.17977/tk.v17i1.7276

Sudaryanto. (2015). Metode dan Teknik Analisis Bahasa. Yogyakarta: Duta Wacana University.

吴岗. (2018). 城市化进程中城市新移民的语言选择－以长沙位列. 黑河学刊， 240(6), 1. https://doi.org/10.1017/CBO9781107415324.004 